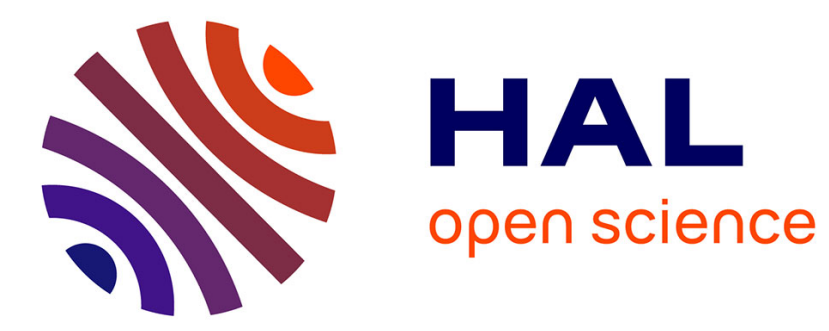

\title{
Metacognition to learn how to write texts at school and develop motivation to do it
}

\author{
Anne-Marie Doly
}

\section{To cite this version:}

Anne-Marie Doly. Metacognition to learn how to write texts at school and develop motivation to do it. Effective Learning and Teaching of Writing, 2003, Stafford, United Kingdom. pp.381-392. hal-00835071

\section{HAL Id: hal-00835071 \\ https://hal.science/hal-00835071}

Submitted on 18 Jun 2013

HAL is a multi-disciplinary open access archive for the deposit and dissemination of scientific research documents, whether they are published or not. The documents may come from teaching and research institutions in France or abroad, or from public or private research centers.
L'archive ouverte pluridisciplinaire HAL, est destinée au dépôt et à la diffusion de documents scientifiques de niveau recherche, publiés ou non, émanant des établissements d'enseignement et de recherche français ou étrangers, des laboratoires publics ou privés. 


\title{
METACOGNITION TO LEARN HOW TO WRITE TEXTS AT SCHOOL AND TO DEVELOPP MOTIVATION TO DO IT
}

\author{
ANNE-MARIE DOLY \\ AUVERGNE UNIVERSITY INSTITUTE OF TEACHER TRAINING, CLERMONT- \\ FERRAND
}

\begin{abstract}
This chapter presents a study carried out in four several final year elementary school (for pupils of 10/11 years old ) and two college classrooms (12 to 14) during a period of six years and its different theoretical references. The aim was to teach pupils how to write narrative texts while developing motivation for this task. Metacognition was chosen as a tool for learning because it is at the same time: (1) an efficient strategy to manage a task throughout, by the pupils using self-control over their own activity (through the processes of forward planing, autoregulation/monitoring and evaluation) which requires awareness of activity, meta-knowledge of the task and especially a knowledge of the "evaluation criteria" (which describe what is the aim to be achieve) and of the "procedural criteria" (which describe how one can manage to write narrative texts)., and (2) a good way to develop motivation, throughout the development of self-concept, the knowledge of oneself as a learner, the feeling of self-efficacy and internal locus of control.

We think that: (1) this metacognitive learning needs several conditions we explain and describe; (2) using metacognitive strategy will be really possible for pupils if they can construct themselves the two types of criteria, and (3) one of the main condition is that this work can't be done by the pupils alone, they must be help systematically to do it by the teacher. So we had to define this sort of help (ie what he has to aim and how) by the reference to the notion of mediation and tutoring.

So, after an account of the research - theoretical references, work hypothesis, action plan and conditions of implementation, modalities and content of evaluation - we present the different steps of the modelisation we carried out after six years of practising in several forms.
\end{abstract}

Key-Words: Metacognition, writing text, self-regulation, evaluation, assessment, procedural criteria, motivation, locus of control, self-efficacy, tutoring.

\section{INTRODUCTION}

In such a written cultural tradition as ours, knowing how to write is essential for the appropriation of a culture. Actually, writing is useful for the handing down of the culture and for its construction. At the same time, it enables us to acquire a freedom and citizen's behaviour for which critical and reflective reason is essential. We know, with J. Goody (1979) the connection between the emergence of the reason, 
the scientific thought and writing. We can understand that learning to write has always constituted the major goal of schooling since its origin.

Learning to write has become much more difficult, particularly when pupils had to write not only isolated sentences or paragraphs but real texts. Psychological and psycholinguistic researches (see Hayes and Flower pattern 1980, Fayol 1985, Gombert 1991) resumed by didactitians (Garcia-Debanc 1984, Charolles 1984, Rosat, Dolz \& Schneuwly 1991, Roussey \& Piolat 1991, Rémond 1999) have emphasized the different cognitive processes - planing, putting in text ("mise en texte"), revision. Now, for these mental processes, metacognitive control is indispensable, so the cognitive cost is important, especially for novices.

These difficulties, internal to the task, are not the only ones. Writing is less and less used and its meaning may become lost in our society as oral language and image tend to be preferred: they are less cognitively demanding especially as for metacognitive work required for writing.

Writing is thus both difficult and depreciated: it neither represents a motivating activity nor a motivating learning curve for pupils, particularly for those who are underprivileged. Actually, metacognitive abilities, (mainly for language mastery), which require distance, reflection, and awareness, which are also necessary to the individual's internal control, are analysed by Lahire (1993) from pupil's written productions as one of the essential abilities lacking in those who are identified as failure in school. Now, these pupils come in the main, from underprivileged social classes which are dominated by types of oral tradition, even when school, which hands down writing tradition, requires metacognitive capacities without learning it (Rochex, 1995).

We can understand the importance and the benefit of metacognitive work about these two aspects of efficiency and motivation mainly for these underprivileged pupils. And teaching them metacognitive skills, through learning to write texts, could be very useful in a society where they are indispensable tools for constructing social and cultural identity.

\section{THEORICAL DATA ABOUT METACOGNITION ON WHICH OUR RE- SEARCH IS BASED}

\subsection{About its definition}

Metacognition consists of two elements (Flavell 1985, Yussen 1985, Doly, 1998, 1999):

1) metacognitive knowledge - true or not - that the individual has about "cognitive processes" (Flavell, 1985): cognitive functioning - particularly one's own about strategies - those he's got, those he's not got - about task - writing for example - and about "cognitive products": what he knows - and does not know- about knowledge;

2) control processes: predicting, guessing, planning, monitoring (self-regulation) and evaluation. These processes are carried out by sudden awareness ("prises de conscience") on what one is doing to reach the aim; this awareness enables him with two things: (1) they stimulate metacognitive knowledge useful for monitor- 
ing and (2) they put proceedure and aim in relation in order to execute selfregulation.

It will thus be advantageous for teaching writing text, that pupils learn how to control their writing activity by self-regulation with true metacognitive knowledge which has been constructed by them with the help -but a special one- of the teacher.

\subsection{About its role and efficiency}

\subsubsection{Metacognition is related to success and transfer}

The main results of metacognition's researches show that using metacognition promotes success in managing tasks and transfer of their results. So, many researches (Yussen, 1985, Gaveleck \& raphael 1985, Paris \& Winograd 1990, Ostad 1999) show connection between metacognition and:

- $\quad$ progress in learning (Paris \& Winograd) and success in problem solving task

- transfer of strategies and knowledge (learnt with metacognition)

- school achievement and more precisely, attainment of skills to learn. Good pupils are told "learning experts", "transferors" and "self-regulated" (BouffardBouchard, Parent \& Larivée, 1991a, 1991 b). In point of fact, they are metacognitive in their way of managing their tasks - they anticipate, guess, plan, selfregulate, self-evaluate, whereas schools less able pupils throw themselves into task without any awareness or self-regulation.

Studies on L.D. (Learning disabled) (Cullen, 1985, Wong 1985) show that their deficiency is mainly metacognitive - they could have knowledge and strategies but they are not aware of it and they don't know how to use them when necessary. These studies also show that the learning of metacognitive skills is possible -with some necessary conditions- and it improves the performances. ( Mélot, 1991, Mélot \& Corroyer 1992, Cauzinille-Marmèche 1991, Doly 1998, 2002).

If several researches are cautious about the correlation between metacognition and transfer because of the difficulty to assess it -what we meet with in our own work-, correlation with metacognition is much more reliable.

\subsubsection{Metacognition is related to motivation (Cullen 1985, Paris \& Winograd 1990, Van Kraayenoord \& Shneider 1999, Bräten \& Olaussen, 2000, Doly, 1996, 1998)}

A very frequent result of metacognition researches, especially those on the LD, is that metacognition develops motivation. Motivation can be particularly seen in involvement into tasks and in perseverance despite failures. This is what mainly appears in our own work in the classroom (2.2.). What is necessary for pupils to develop motivation? and what is noted as developed by motivated pupils ?

1) they must find sense in their task ; and in order to do that, they need to have a representation of the task by its goal and/or it's finality (to be able to control their activity). 
2) they must have metacognitive knowledge : motivated pupils know themselves as learners and they know what knowlegde they possess (about strategies, task and knowledge) ("they know what they do know and what they don't know yet", Rochex, 1995).

3) They must attribute their performances to their own control (internal attribution): "their actions are indeed what is responsible for their performance" so " their failure is never inescapable and uncontrollable " (Paris \& Winograd) ; so, effort is always possible and stimulating for pupils because they "are aware of their power of control and monitoring".

4) They must develop "self-efficacy feeling" (Bouffard-Bouchard \& Co, 1991 b), that is the ability to perceive oneself as efficient and to construct a positive self concept throw the different school activities, performances and assessments.

This feeling is linked with metacognitive activity : " the perception of oneself efficiency plays a role of mediation between one's current capacities and his ability to use them adequately. ... It could have higher effects on self-monitoring than cognitive skills themselves (...)" (Paris \& Winograd, 1990).

So, motivation is closely connected with metacognition : on one hand, metacognitive pupils show these motivational behaviours, and on the other hand, making pupils use metacognition requires and develops those motivational behaviours (Bräten \& Stokke Olaussen, 2000) : that constitutes one of my main hypothesis of work.

2.3 About the conditions of practising metacognition (Cauzinille-Mamèche 1991, Mélot \& Corroyer, 1991, Fayol \& Monteil, 1994, Doly 1998, 2003 under press)

Conditions stated under, come from my own work in the classroom, (they were those necessary to practise metacognition in class , 2.2.), and from other's, reported in literature about metacognition.

1) Pupils need some previous available metacognitive knowledge in the concerned field to enter the task.

2) They must be able to activate this knowledge when necessary : this ability depends on age, but mainly on the method of training, on the way of helping, and on the way this knowledge has been acquired and put in the memory for transfer, which implies three other conditions:

- $\quad$ pupils must have a representation of the goal (especially by evaluation criteria which describe the final situation) and keep orientated to it.

- they must be aware of parts of their activity while it goes on, and at its end, in order to understand what they are doing, in order to assess the benefit of this way of coping by making the relation between procedure, goal and performance.

- "the key of the transfer would consist in the ability of the individual to work out the particular solutions into an abstract level, what requires abstracting the properties and the fundamental connections of the situation." (CauzinilleMarmèche, 1991 AAD PAGES IF YOU QUOTE: I HAVE NOT KEPT THIS ARTICLE OF “LE BULLETIN DE PSYCHOLOGIE” BUT THERE IS ONLY 
ONE ARTICLE BY THIS AUTHOR). So, the individual has to "discontextualize" knowledge and procedures, and to conceptualize them in order to make them able to be generalized (see work in class about criteria cards made by pupils). This work to abstract is close to the three levels of abstraction of Piaget (1974) ("empirique", "réfléchissante" and "réfléchie" that the individual has to get over from "intelligence sensori-motrice" to "intelligence opératoire" using sudden awareness.

3) This re-working out ("ré-élaboration"), very often made by writing prepared by oral communication between pupils and teacher, has to be executed by the pupils themselves and not by the teacher, even if he has to help them to do it.

4) Metacognitive behaviour is not spontaneous for pupils and we do not note it in the forms where the teacher has not anticipated and prepared it precisely. Thus, the "mediation" of the teacher is indispensable and it is essential to define it (Doly 1998,1999, 2000).

The mediation of the teacher must be understood as a tutoring. This concept comes from Bruner (1983: 261) who refers to Vygotsky's thought on intellectual development and his idea of child social and cultural development by "internalization" (interiorisation) (1985: 111).The whole literature on this point (Day \& Co, 1985) refers to this frame Vygotski-Bruner. These references as well as my work in classes allowed me to define this sort of mediation. It means that the teacher has several things to do:

- to construct a conceptual organization of knowledge, didactic and pedagogical objectives,

- to prepare the lesson in order to make pupils use metacognitive abilities,

- to choice an adequate situation for learning,

- to use a particular way for his intervention which must neither be sanctioning, nor prescribing but questioning, helping to and asking for re-formulation on what the pupils are doing to attain the goal.

Tutoring has to help pupils become aware and make different cognitive operations necessary to execute the metacognitive control of their own activity (and the discontextualisation/conceptualization) without never doing it instead of them. This way of helping must be internalized by pupils so that they will be able to "help themselves" (Bruner, 1983, Doly, 1998, 1999).

These references, to which it should be added didactic knowledge about narrative writing text not exposed here, constitutes the background knowledge of my work in the classrooms.

\section{PUT IN PRACTICE}

\section{HOW WORKING IT OUT AT SCHOOL TO ENABLE PUPILS TO LEARN WRITING TEXT USING METACOGNITION AND WHAT DOES IT MEAN?}

We have to teach pupils to write narrative texts with metacognition abilities in its two aspects of knowledge and of internal control : the teacher has to make pupils to construct metacognitive knowledge about tasks, strategies and their own skills and 
difficulties in this area, that they will be able to use in order to monitor their own activity of writing .

\subsection{Methodology}

The hypotheses of this work are based on researches about metacognition in its connections with task management and conditions for self-regulation, and with motivation:

- using metacognition makes training and progress in writing texts easier for pupils;

- it is possible, if the four conditions stated formely are respected, especially the way of tutoring, to make pupils construct metacognitive knowledge, particularly the one concerning evaluation criteria (which define the goal) and the one concerning proceeding criteria to control their writing activity;

- this metacognitive way of learning develops motivation for writing texts : it develops a self knowledge about the task, procedures and strategies, what is easy- what is difficult for him, it develops internal attribution, and the feeling of self-efficacy and, at least a positive self concept.

In other words, this metacognitive way of learning develops both the pleasure of writing and the ability to do so (see further the interviews), which widely helps learning.

Device and Evaluation. Our method is qualitative. I worked in four different classrooms (age: 9-11) and two classrooms in college (12-15) during a period of five years; I have worked out progressively a pattern to use metacognition at school with pupils. The assessment of this work has been made in several ways:

- The teachers made regular assessments (required by school);

- We analysed answers to questionnaires and interviews systematically carried out on the pupils and on the teachers;

- We compared pupil's answers of different classrooms, especially with those without metacognitive work.

Some difficulties still remain. There has been only one comparison with a classroom without metacognition work (as control group). The study of starting data was made only through teacher's and pupils reports. Evaluation of transfer and it's connection with metacognition is very difficult in natural classroom situation. This way of teaching requires a special training for teachers as much on theoretical basis as on the question of tutoring which is not a usual way of teaching.

\subsection{Modelisation: Description of the Process in 9 steps}

This work required an important work to prepare the lessons: it must concern didactic objectives (which knowledge and skills in the subject are aimed? and how?) and pedagogical objectives about metacognitive abilities and motivation. 
1) Didactic objective: learning to write narrative text; operational objective: making pupils construct evaluation criteria (which describe the goal) and procedure criteria.

2) Pedagogical objectives:

- teaching pupils self knowledge about themselves in writing activity in order to better control and monitor it in connection with its criteria;

- developing self efficacy feeling and motivation to write concurrent with ability, and a positive self concept (helping pupils to become aware of being able to write narrative texts in order to like it and do it).

Step 1. The teacher advises the pupils of the work's modalities and objectives.

Step 2. He makes pupils to bring out a first list of basic evaluation criteria : it is about having them emerge meta-knowledge on the task to allow them in monitoring to a minimum their writing output.

1) Each pupil writes a text on a subject chosen by the teacher who only helps those in difficulty to allow them to take part in following sessions.

2) He assesses texts on a separate card, he notices difficulties and errors found for each pupil and for the whole form according to the most frequent and to its didactic objectives, those he will use to choose evaluation criteria that he wants pupils to find and use to write at other times.

He selects two or three texts:

- one represents a good text (according to the criteria)

- the others show, the most clearly, the errors he should like the pupils to become aware of, in order to have them find the criteria which will be used for the rewriting of their texts.

The teacher types these texts and eliminates irrelevant variables.

Step 3. He distributes these texts to pupils, who are put in pairs. They are asked to assess them on a separate card, writing : "what goes well and what does not"; "what could it be written for the writer to help him to improve his text". During this work, the teacher helps systematically and by tutoring (as described above) if anyone needs: he helps them to pass out of an intuitive and global assessment into a precise and explicit one (Vygotsky, 1985): "school makes pupils pass from unconscious to conscious and wilful"); to make them progress in the representation of the goal by criteria to re-write in a better controlled way. At the end, he starts to question them about their procedures to help them to understand the question (new for them) to come back to it afterwads.

Step 4. He gathers these assessment cards, he assesses them to know who perceived what in the texts, which criteria have been found and which have not, and makes a synthesis. He wants to know two things : who are the pupils who have the greatest difficulties in evaluation, that is to say to perceive what must be done to write well, that is to say again to perceive and use the evaluation criteria ; which difficulties 
have been perceived by the pupils in the texts and those which have not, to be able to prepare and conduct the next collective oral lesson that must be allowed to set up the list of criteria.

Examples of pupil's evaluation:

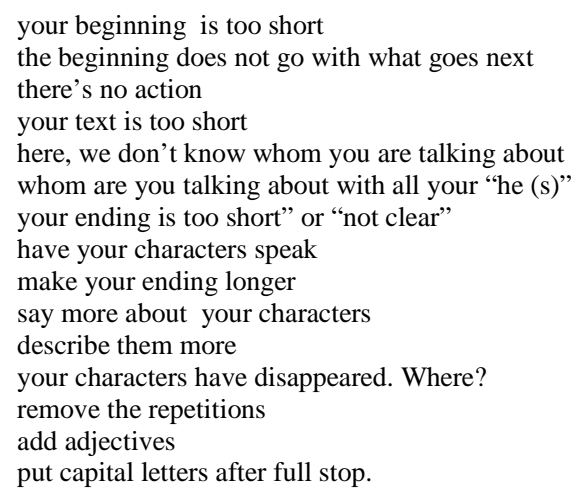

The hypothesis retained there (Bruner ADD YEAR OF PUBLICATION 1983 p. 263/264) is that the capacity to evaluate comes before and allows production: "the understanding of the solution (that is also to say, of the goal) must come before its production.(...) That is to say that the learner has to be able to recognise a good solution (...) before being able himself to produce the processes which lead to it without help" and the progress can only be done with help of an expert tutor. That is why we make pupils practise evaluation before re-writing and in order to do it with better chance of progress. And they evaluate not only before writing and to help their re-writing, but they also construct for themselves the evaluation-criteria necessary to write: we are much more certain that they may be able to use these criteria to control their own writing activity (criteria are in their "proximal zone").

Step 5. He guides an oral and collective lesson of assessment which must lead pupils to a discontextualization/ conceptualization of evaluation-criteria : the teacher gets pupils to do for themselves this work of abstraction and explicitation of criteria by tutoring. The pupils set out the criteria they found, discuss to keep those more pertinent, according to the didactic objectives and to formulate them precisely. The teacher writes the criteria on the board, classifies them in local aspect (microstructure: word and sentence level, style,), and in total aspect ( macro-structure level, narrative organisation and marks) so that the pupils have a double card. For example:

Card for local criteria:

- Mind repetition of words - mind punctuation (full stop and capital letter after it, inverted commas when somebody is speaking ) - mind not changing tense without reason - we must know who/which/what we are speaking about when we write "he", "she" "it", "her", "his" "its" - find attractive words to describe.

Card for total criteria (example taken after two lessons): 
- In the initial situation, we have to present the characters, to say where and when the story takes place, to tell pertinent details for story - there is a hero and other characters, and something happens to him (there is a problem) the hero sets up a plan - there may be sudden changes of fortune - the story must have an ending and we must know what happened to the characters introduced in the beginning - be aware also of spare texts : it is possible to make the text longer with descriptions or dialogues - we have to find a title in connection with the story.

These criteria evolve as pupils learn and have developed their abilities: some disappear, new ones appear. During this oral lesson, pupils already show that they become aware of their own mistakes (the teacher helps them to realise that because he knows their texts and their errors). The teacher saw the evaluation cards of pupils and knows who is having difficulty, who has to take part in the discussion to understand better, plus what was difficult for all of them: so, he intervenes to focus attention on some points, to encourage some pupils to speak. His purpose is to make pupils go beyond the local and empirical level towards a more conceptual and generalized level. This guidance by tutoring requires from the teacher, listening, availability, and trust in the capacity of pupils to descover what the teacher would like them to learn. So, at the end of this lesson, pupils have a double card of evaluation criteria.

They frequently asked for another card for resistant errors. This card has generally been called "mind!" and it can be different for each pupil (we can note that we very often came across the same difficulties in the different classrooms): Example for card "mind":

Not too many sudden changes of fortune - no explosion of things or characters into text or their sudden disappearance - no changing tense - no use of familiar or rude words - use "pretty" words to describe - do not copy the TV series (we read a text which made changes of fortune by copying every sentence from TV script)

Step 6. At the end of this first work and more in following sessions (after rewriting), the teacher questions the pupils about their procedures: "how have you managed writing your text?" " how did you started writing ?" "is there anything which helped you ?" "which has been the most difficult?" "how do you know you have done what is right according to criteria?”.

This reflection of the pupils, which is first oral and collective then individual and written (as described for the other card) leads to a card for proceedings (" proceeding criteria") used for the re-writing.

Four goals are aimed for this work: pupils must become aware (1) of their own proceedures); (2) that there are other procedures than their and which ones they are; (3) that there are some more efficient than others; and, (4) of the benefit of changing if necessary, and how to go about it.

Example: (we can note here again that we find generally the same procedures in the different classrooms): The pupils who have generally done their text well or rewritten it say: 


\begin{abstract}
"I go through the story in my head before writing"; "I imagine all the story in my head and then I write it" ; "after, I find the words to write"; "I only need to write; "in my head, I imagine a "narrow" text, and when I write, I widen it. "I think very quickly of the ending"; " when I start, I ask myself how my story is going to end"; "I write first in my rough book, I've seen things which did not fit right with the card, so I put it right in my head" "I first think of what should happen to my hero"; "yes, but it's difficult to get the beginning started !" "I think of the characters very quickly"; "I choose a hero" ; "I remember other stories I've read, it helps me" . "I remember a R. Dahl story, I use it as a model" "I choose the title after writing the text"
\end{abstract}

They actually planned their text, some of them enter writing via the characters. The pupils who have not succeeded in writing say:

"I've done my text small bits after small bits"; "I write as ideas come in my head"; "I write as and when required" ; "I choose title at first".

Once, after we noted that "small bits after small bits" could not be an effective way, a pupil said after his own assessment:

"I've done small bits after small bits but my text is not so bad"; the teacher asked :" How did you do it ?" -"I re-read after every new small bit to see if it went with the others, it is necessary that all pieces go together".

Another pupil said:

"I add special words to connect the sentences or the paragraphs", (that made occasion for a lesson about transition).

So, after it's been written on the card of procedure criteria :

"it's better to first set up (or imagine) all the story in one's head"; "we can first of all imagine the characters" ;" we can think of the end before the beginning" ; "it is often better to get the title after writing the story"

We added :

"if we write small bits after small bits, we must think of the links between them together with the beginning"; "we must re-read to see if all the pieces go together" ; "it is necessary to remember the beginning while writing"; "it's good to re-read aloud one's own text to be sure it is coherent" (this last concept had been worked) ;"we must take care of transitions"

Cards are tools: the pupils use these cards as they find necessary for them, with the help of the teacher.

Step 7. The pupils individually evaluate their own text with the cards : the teacher helps them (still by tutoring) to see what needs putting right in their text still in accordance with the criteria they know now. Moreover, they ask for the teacher's help in connection with their cards:

"I can't make a sudden change in circumstances which looks true" ; "I' can't find a good ending for my story"; " I can't find a good word which avoid the repetition of "he"; "I can't get a title which goes with my story".

A pupil answers the questionnaire:

“ it's often me who calls R. (the teacher), I ask her to help me to write with the card"?. 
The teacher has to help the pupils who are having difficulties to select the criteria (three or four) they will have to use for re-writing in order to avoid over cognitive load.

Step 8. Each pupil re-writes his text : the teacher helps them when they need it. We noted that they never again said "I can't do anything" or "I've no ideas what to write": they always ask for precise questions connected with criteria.

Step 9. The teacher evaluates this re-writing annotating the paper itself : he says what is better, what is not (still in connection with criteria), what should be put right if the pupils re-write one more time. He avoids negative comments and prefers something like "find a more attractive word" or " one that is less familiar", "rewrite this sentence, it's not very clear", "add a sentence to give a better explanation", "re-write your ending", "find a tittle which fits better with your text", "find an other end which goes better with your story", etc. Most of the pupils want to re-write their text again without requiring help from the teacher : this is a good sign of motivation.

\subsection{Some results of questionnaires analysis}

We note that there is not a pupil who does not make any progress in the writing of narrative text according to teacher's didactic objectives. Most of the pupils wanted to re-write their text twice because they had become sure that they could do better than the time before: this behaviour is very characteristic of motivation, which is seen in the answers to the questionnaires. This way of working in the classroom was used in other branches of learning (mathematics, spelling, English learning, in secondary forms (16/17): we noted that this behaviour of motivation is always shown. The pupils showed clearly self-efficacy feeling and internal attribution, which are explicitly linked with the pleasure of working in that way.

This way of teaching uses systematically and at each steps, the communication between pupils: it promotes metacognitive behaviours and it also allows the avoidance of subjective and negative judgements on texts, pupils use technical ones only ; I never saw a pupil afraid of the evaluation of his text ; on the contrary, they are not pleased if their text is not chosen for collective assessment ("after collective evaluation of our text, it is much easier to re-write”, said a pupil).

Examples of answers. The answers show a connection between better capacity and knowledge about the task of writing, a better meta-knowledge of oneself as learner in this task, and the pleasure of writing ; pupils clearly develop motivation by doing the writing task itself. A pupil lists all what he could not do before. We can find criteria through the meta-knowledge he shows: and he adds: "now I know what I have to do when I have to write a text". An other pupil in failure said : "I know why I did not succeed at the first time, it's because I wrote small bits after small bits ; now, I try to imagine the whole story in my head before writing". An other : in the beginning, I did not like to write at all, and now, I know how to do, so I write more and I 
like it much more" "what remains just as difficult for me, it is the conjugations and tenses of verbs, and telling a story with "I" as the subject " "I like working like that very much because it's a bit as if we were the teacher"

About the role of the card as a tool and meta-knowledge: "I look at the card to remember what is necessary for me - about spelling, presentation of the characters, etc., but I don't use it anymore for "structure", I have it in my head now". We found the same sort of answers in all the classrooms.

\section{CONCLUSION}

J. Y Rochex (1995), in his research about pupils who are failing, notes that the "project pedagogy" (doing a video, making a film, etc.), often used in these schools to motivate pupils for school work, may distract them from what they must really learn at school (ie.academic subjects), especially those who are in failure who think that school is made for doing these projects and not to learn maths or grammar. Then, they don't understand what they do at school, they mix up motivation - the means and the knowledge - the aim. It is so necessary to look for a way of motivating which could sustain pupils academically, which does not mix up means and aims. We think that the way of learning shown here is a possible answer to this problem: pupils have both learnt and developed how to write texts along with the motivation to do so. They constructed a positive concept of themselves and at the same time, a part of their social and cultural identity.

\section{REFERENCES}

\section{PLEASE CHECK THIS LIST, USING THE APA MANUAL ; I PLACE SOME COMMENTS BETWEEN THE ITEMS. I AM AFRAID THAT 90\% OF THE ITEMS IN THE LIST ARE INCORRECT AND/OR INCOMPLETE.}

Bouffard-Bouchard T., Parent S., \& Larivée S. (1991 a). Compétences cognitives, capacités d'apprentissage et métacognition.(cognitive skills, learning capacity and metacognition). Journal International de Psychologie,26,6, 723-744. ADD PAGES; VOLUME NR IN ITALICS, ISSUE NUMBER IN REGULAR FONT. ADD FOR TILTE SIN A NON-ENLGISH LANGUAGE, A TRANSLATION INTO ENGLISH BETWEEN [BRACKETS ].

Bouffard-Bouchard T., Parent S., \& Larivée S. (1991 b). Influence of self-efficacy on Self-Regulationand Performance among Junior and Senior High School Age Students. International Journal of Behavioral Development, 14,2, 56-79.

Bräten I. \& Olaussen B.S. (1997). The relationship between motivational beliefs and learning strategy use among Norvwegian college students. Contemporary Educational Psychology, 23, 182-194.

Bruner J. (1983). Le développement de l'enfant. Savoir Faire, Savoir dire (PUF, Paris).(The child deve-

lopment. Knowing to do, knowing to say).

Cauzinille-Marmèche E . (1991). Apprendre à utiliser sa connaissance pour la résolution de problèmes : analogie et transfert (Learning to use one's cognition for problem solving. Comparisons and transfer). Bulletin de Psychologie, Tome XLIV, 399.156-164.

Cullen J.L. (1985). Children's ability to cope with failure : implication of a metacognitive approach for classroom. In D.L. Forrest-Presley, G E. Mac Kinnon, \& T. G. Walker (Eds.), Metacognition, cognition and Human performance, vol. 2, pp. 267-300. INC, Orlando, FL. Academic Press. 
Day J.D., French L.A. \& Hall L.K. (1985). Social influence on cognitive development. In D.L. ForrestPresley, G.E. Mac Kinnon, \& T.G. Walker (Eds), Metacognition, cognition and Human performance, vol. 2, pp. 33-54. INC, Orlando, FL. Academic Press

Doly A-M. (1996). (a) Motivation et métacognition (motivation and metacognition), .(b) Réussir pour motiver (succeeding to motivate).Cahiers Pédagogiques, «La motivation» (the motivation), 59-63, 70-74. Doly A-M. (1999). Métacognition et médiation à l'école(Metacognition and Motivation at school), In, $M$. Grangeat,(Eds) La métacognition, une aide au travail des élèves (Metacognition, an help for pupil's work) 17-61. ESF, Paris.

Doly A-M.(1998). Métacognition et Pédagogie : enjeux et propositions pour l'introduction de la métacognition à l'école.(Metacognition and Pedagogy : Aims and Propositions for introduction of Metacognition at school) Thèse de Doctorat, Lyon 2 University.

Doly A-M. (2000). La métacognition pour apprendre à l'école, (metacognition for learning at school) Cahiers Pédagogiques,381, 35-40.

Fayol M., Monteil J-M. (1994). Stratégies d'apprentissage/apprentissage de stratégies.(strategies of learning/learning of strategies) Revue Française de Pédagogie, 106, 91-110.

Fayol M. (1985). Le récit et sa construction,une approche de psychologie cognitive (The narration and its building up.An approach of cognitive psychology): Delachaux et Niestlé ,Neuchatel,Paris.

Flavell J.H. (1985). Developpement métacognitif (metacognitif development). In Bideaud J. \& Richelle M (Eds), Psychologie développementale, problèmes et réalités. (Developmental psychology, problems and realities) pp.30-41 : Mardaga,.

Garcia-Debanc C. (1986). Intérêt des modèles du processus rédactionnel pour une pédagogie de l'écriture, (Advantage of models for redactionnels procedures for writing training) Pratiques, 49, 23-65.

Gavelek J.R. \& Raphael E. (1985). Metacognition and the role of questioning activities. In D. L. ForrestPresley, G.E. Mac Kinnon, \& T.G. Walker (Eds), Metacognition, cognition and Human performance, vol. 2,103-136. INC, Orlando, FL. Academic Press.

Gombert J. E. (1991) Le rôle des capacités métalinguistiques dans l'acquisition de la langue écrite (The rôle of metalinguistic capacities in written language acquisition). Pratiques, 3.,114-126.

Goody J. (1979). La raison graphique : Minuit, Paris.

Hayes J.R. \& Flower L.S. (1980).1) Identifying the Organization of Writing Processes ; 2) the Dynamics of Composing : Making Plans and Juggling Contraints. In L.W. Gregg \& E.R. Steinberg (Eds), Cognitive Processes in Writing, pp.5-72. Hillsdale, New Jersey, Lawrence Erlbaum Ass.

Lahire B. (1993). Culture écrite et inégalités scolaires. Sociologie de l'échec à l'ecole (Writing culture and inequalities at school. Sociology of failure at school) : PU Lyon.

Mélot A-M. (1991).Contrôle des conduites de mémorisation et métacognition (control of the memorisation behaviour and metacognition). Bulletin de Psychologie, Tome XLIV, 399 ,138-146.

Mélot A-M. \& Corroyer D. (1992) Organization of Metacognive Knowledge : a Condition for Strategies Use in Memorization. European Journal of Education, vol. VII, 23-37.

Piaget J. (1974). La prise de conscience(The Sudden awarness) : PUF, Paris.

Paris S. G. \& Winograd G. W. (1990). How metacognition can promote academic learning and instruction. In B. J. Jones \& L. Idol, Dimensions of thinking and cognitive instruction, pp.15-33. Hillsdale New Jersey Erlbaum Ass.

Remond M. \& Quet F. (1999). Apprendre à comprendre l'écrit. Psycholinguistique et métacognition : l'exemple du CM2. (learning to understand writing. Psycholinguistic and metacognition : example in classroom of 10-11 years old pupils) Repères, 19, 203-225.

Rochex J-Y., (1995) Le sens de l'expérience scolaire :PUF Paris.

Rosat M., Dolz J. \& Schneuwly B. (1991). Et pourtant... ils révisent. Effets de deux séquence didactiques sur la réécriture de textes (And yet..., they review. Result of two didactic lessons about rewriting.) Repères, 4, 22-45.

Roussey J-Y \& Piolat A. (1991) Stratégies experts de contrôle rédactionnel et définition du but (expert control writing strategies and goal definition). Repère, 4,15-32.

Van Kraayenoord C.E \& Schneider W.E. (1999). Reading achievement; metacognition, reading selfconcept and interest : a study of German students en grades 3 and 4. European Journal of Psychology of Education, vol. XIV, 3, 305-324.

Vygotski L. (1985). Pensée et langage (Thought and language) :PUF, Paris.

Wong B.Y.L. (1985). Metacognition and learning disabilities. In D.L. Forrest-Presley, G.E. Mac Kinnon, \& T.G. Walker (Eds), Metacognition, cognition and Human performance, vol. 2, pp. 137-175. INC, Orlando, FL. Academic Press. 
Yussen S.R. (1985). The role of metacognition in contemporary theories of cognitive development.

In D.L. Forrest-Presley, G. E. Mac Kinnon, \& T. G. Walker (Eds), Metacognition, cognition and Human performance, vol.1, pp. 253-284. INC, Orlando, FL. Academic Press. 